\title{
Probing the efficacy of local economic development in South African Municipalities: A case of POLOKWANE local municipality
}

\author{
CM Mashabela \\ Department of Public Administration \\ University of Limpopo, South Africa
}

\section{Keywords}

Efficacy, Employment Growth, Local Economic Development

\begin{abstract}
The government of South Africa adopted Local Economic Development (LED) as part of its development policy in its quest for an inclusive economic development and growth. LED is intended to create a conducive environment for an inclusive local economy. However, unemployment and poverty rates are high in local communities with some SMMEs struggling to secure funding. Although municipalities do not create jobs directly through LED, they should, however, ensure that strategies implemented talk to inclusive economic growth, particularly the mitigation of unemployment and poverty rates. The purpose of the paper is to investigate the efficacy of LED in South African municipalities. The paper aims to evaluate and analyse the impact of implementing LED in South Africa. The quantitative research approach was adopted, and questionnaires were utilised to collect primary data. The paper found that LED in South Africa produces desired results at a low rate in that only a small fraction of the participants agrees that the municipality facilitates funding for SMMEs; only a small fraction of the participants is of the view that LED units provide adequate infrastructure and create industries. Moreover, the paper found that only a fraction of the participants is able to create job opportunities. Consequently, the paper recommends that municipalities should facilitate $S M M E s$ funding, provide adequate infrastructure, develop industries and design LED strategies that enhance job creation. The paper argues that effective measures of implementing LED will enhance LED impact rate and fast track the prospects of inclusive economic growth in South African municipalities.
\end{abstract}

\section{Introduction}

The implementation of Local Economic Development (LED) is governed by a legislative and policy framework in South Africa. Legislation and policy framework in South Africa mandate municipalities to create a conducive environment for growing local economy (Botes, 2002). The White Paper on Local Government (1998) introduced LED as an element of Integrated Development Plan (IDP) which is used to address developmental issues in the local government. The Municipal System Act 32 (2000) states that LED functions are legislated as part of IDP in the municipality.

The South African government through the LED, supports SMMEs and society as an attempt to create a conducive environment for employment growth as well as poverty alleviation. Although municipalities in South Africa have LED units, only small municipalities have two or three officials responsible for implementing LED. Only category A and some category B municipalities have a fully-fledged LED unit. The role of LED unit includes facilitator, stimulator and co-coordinator (Meyer \& Venter, 2013). LED unit formulates strategies in line with its roles when implementing LED. Municipalities guarantee local economic empowerment and the dynamisation of local resources through LED (Kamara, Leonard \& Haines, 2017). Municipalities must, therefore, develop inclusive local economy with high level of coordination between all spheres of government for LED to have a significant impact on employment growth and poverty alleviation (Kroukamp, 2006).

The central argument of this paper is that, although the government of South Africa uses LED as a tool to mitigate unemployment and poverty rate, the unemployment rate is still high with people still living in poverty conditions. South African provinces have high poverty rates, with the Limpopo province recording $67.5 \%$ of adults living in poverty followed by Eastern Cape with 67,3\%, KwaZulu Natal with $60,7 \%$ and Northwest with 59,6\% (Statistics South Africa (Stats SA), 2019). The unemployment rate in South Africa is $27.6 \%$ and it has increased by 0,5\% as compared to 2018 (Stats SA, 2019). The increase in 
the unemployment rate has resulted in the decline of employed people in 2019 as compared to 2018 (Stats SA, 2019). It has been almost 27 years since the inception of LED and yet its impact is declining. In light of the foregoing assertions, this paper aims to probe the extent in which LED impact local economy in South African with reference to Polokwane Local Municipality.

\section{Literature review}

\section{Nature and strategies of led in SOUTH AFRICAN municipalities}

LED in South Africa has four facets, namely, coordinator, facilitator stimulator and entrepreneurship. LED is multidimensional in nature (Nel \& Rogerson, 2002), is integrated with other programmes in the municipality and all the spheres of the government (Malefane, 2009). LED agencies support and promote LED initiatives in South African municipalities. The local government uses LED agencies to assist and promote LED initiatives. LED promotes entrepreneurship in local municipalities. Municipalities provide both financial and non-financial support (Binza, 2005). Municipalities can either operate an enterprise or join partnership with the private sector and other stakeholders (Koma, 2014). Municipal enterprises increase municipal revenue (Mbecke, 2015).

There are a number of LED strategies in South African municipalities, such strategies stem from the four facets of LED. The LED strategies include support and promotion of SMMEs, provision and maintenance of infrastructure, attraction and retention of SMMEs, promotion of exports and import substitution, human capital development and community economic development. The White Paper on National Strategy for the Development and Promotion of Small Business in South Africa mandates municipalities to mitigate unemployment through SMMEs and eradicate inequality through Black Economic Empowerment (Makhubo, 2015). There is a large number of SMMEs programmes in South Africa that assist SMMEs with access to finance; research and information, training and development, markets and linkages, (Meyer, 2014b). Provision of infrastructure promotes employment growth (Bond, 2002). The demand for infrastructure demand is high while the resources for provision of infrastructure are limited (Oyedele, 2012). Provision of infrastructure is a yardstick to benchmark good leadership and governance (Oyedele, 2012). SMMEs in local municipalities can be attracted and retained through the provision of adequate infrastructure and service (Slabbert, 2004). Municipalities can promote export and import substitution by supporting local businesses to produce and export competitive goods (Slabbert, 2004). Municipalities can also promote LED through the promotion of local markets (Reddy, Sing \& Moodley, 2003).

\section{Research methodology}

This paper used the quantitative research design and administered questionnaires to collect primary data. Questionnaires produce straight-forward answers and promote confidentiality. The paper used the Polokwane Local Municipality as its study area and its target population was people and SMMEs that received services from the LED unit in Polokwane Local Municipality. The researcher circulated 370 questionnaires to the beneficiaries of LED (street vendors and SMMEs) in the Polokwane Local Municipality. The beneficiaries of LED receive services from the Local Development unit. The data collected through questionnaires was analysed using Microsoft Excel 2010 and was presented in statistical form.

\section{Findings}

The questionnaire distributed was structured based on the strategies and role of LED in South African municipalities. The findings are as follows: 
Figure 1: LED unit facilitate funding for SMMEs

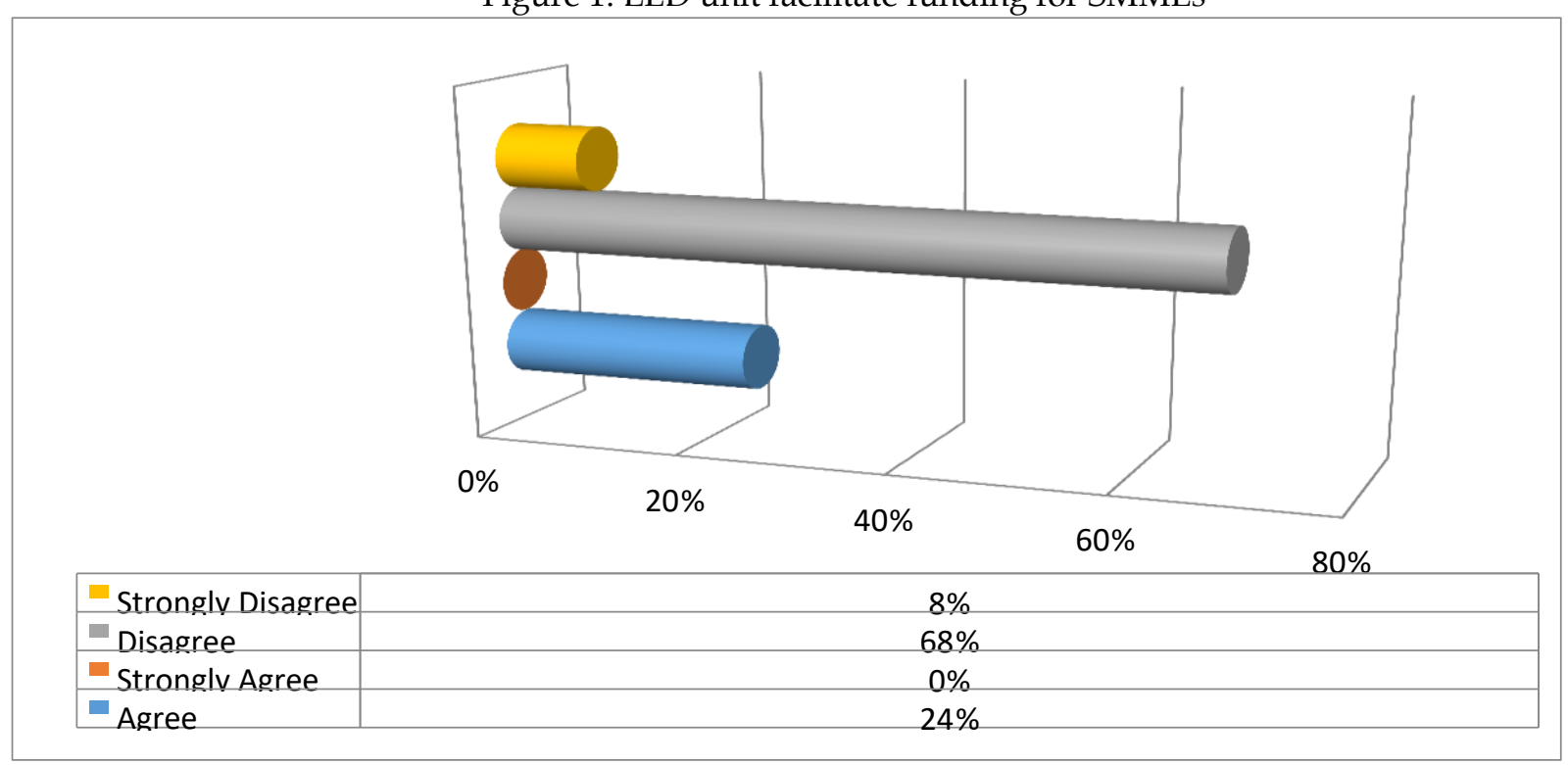

Figure 1 shows that $8 \%$ of participants strongly disagree, followed by $68 \%$ of participants that disagree. $0 \%$ of participants strongly agree and $24 \%$ of participants agree that LED unit facilitates funding for SMMEs. In total, the majority of participants $(76 \%)$ are of the view that LED does not facilitate funding for SMMEs. A fraction of $24 \%$ (participants) holds different views. The finding backs the assertion that SMMEs funding is inaccessible in Limpopo Province (Ladzani \& Netswera, 2009).

Figure 2: LED unit provide sufficient infrastructure

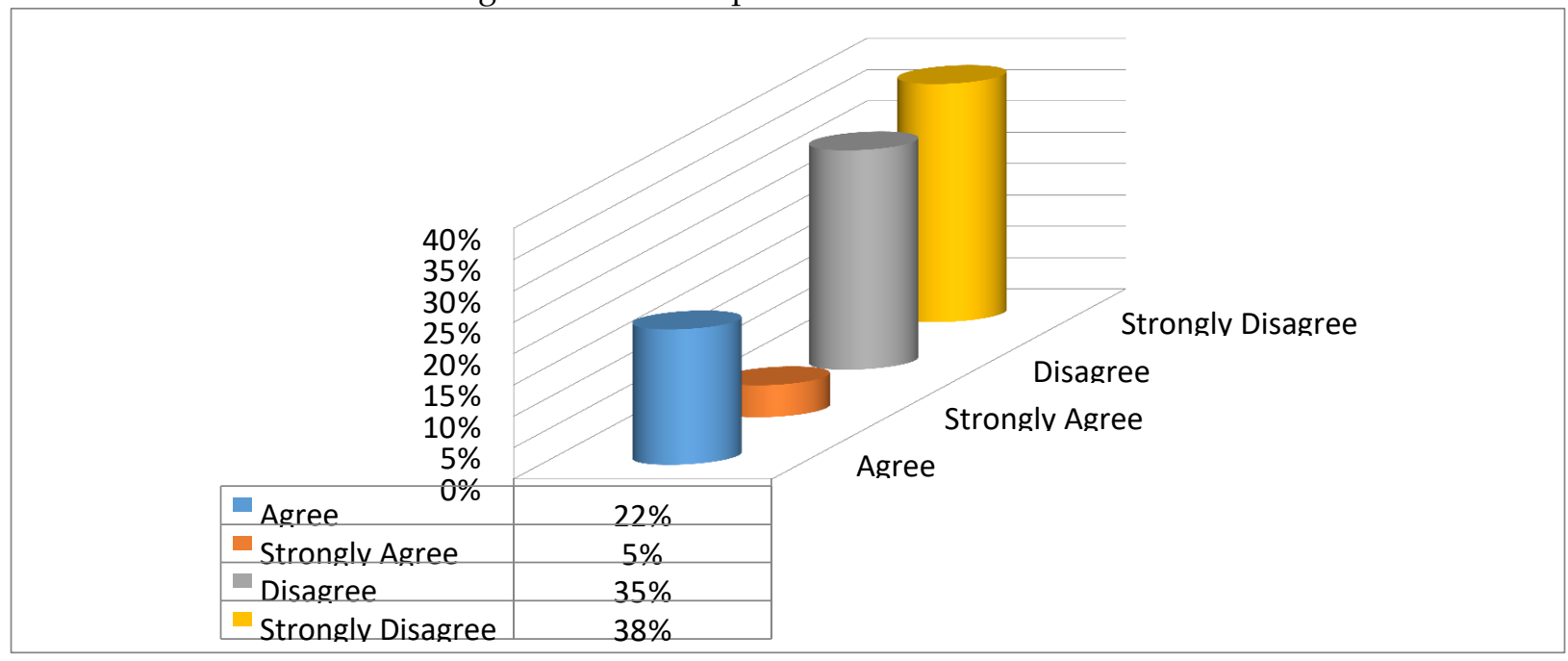

Figure 2 shows that $22 \%$ of participants agree, followed by $5 \%$ of participants who strongly agree. $35 \%$ of participants disagree and $38 \%$ of participants strongly disagree that the LED unit provides sufficient infrastructure. In total, the study shows that $73 \%$ of the participants are of the view that the LED unit provides insufficient infrastructure. Only $27 \%$ of the participants have a different perspective. The findings suggest that there is an inadequate provision of infrastructure for the implementation of LED. The finding supports the assertion that there are infrastructure backlogs in South Africa (Lombard, Behrens \& Viruly, 2017). 
Figure 3: LED unit creates industries in the municipality

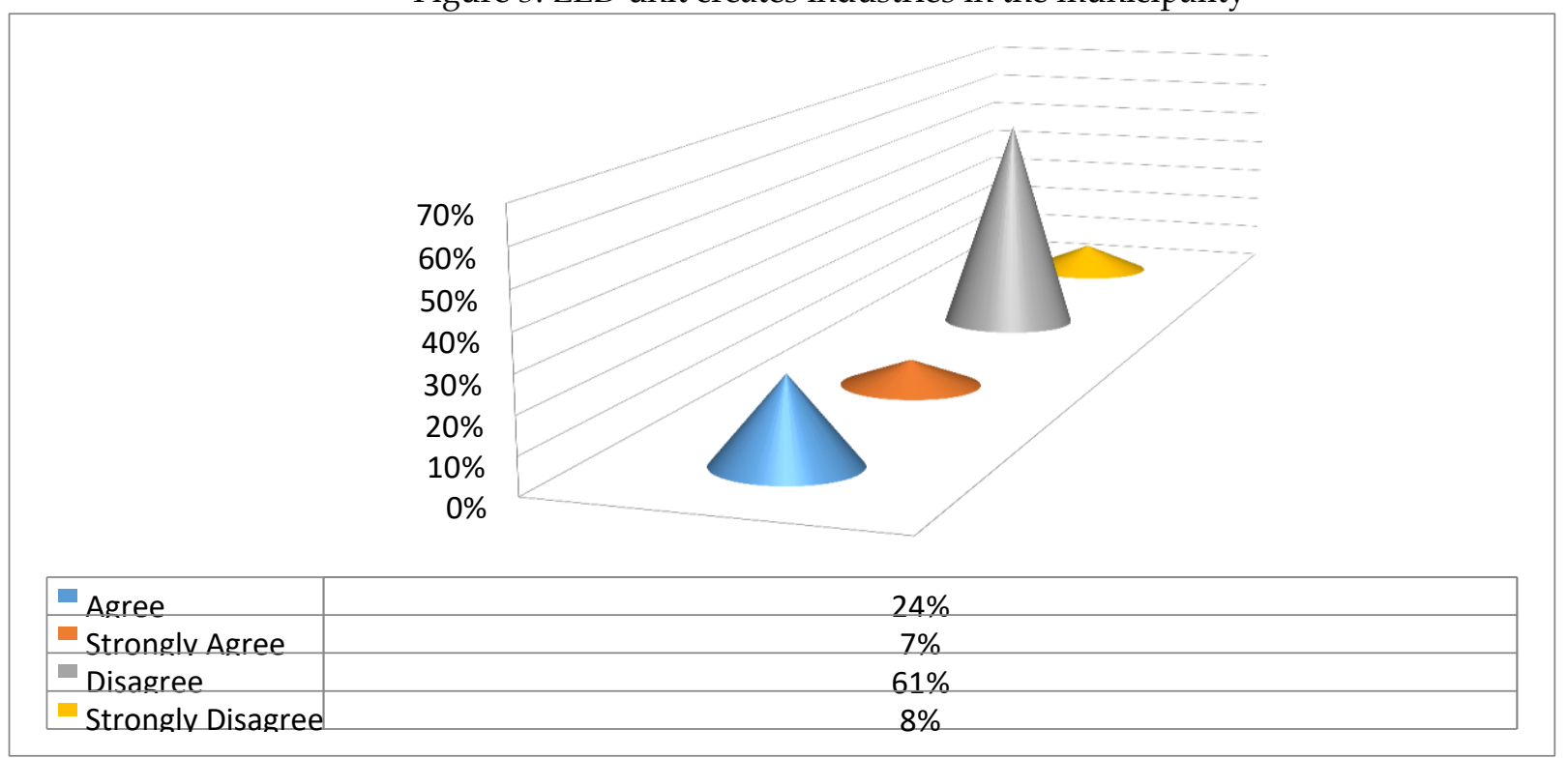

Figure 3 shows that $24 \%$ of the participants agree, followed by $7 \%$ participants who strongly agree. Majority of the participants disagree at $61 \%$ and $8 \%$ of participants strongly disagree that the LED unit creates industries in the municipality. The overall perception here is that $69 \%$ of the respondents are of the view that the LED unit is not able to create industries in the municipality. Only a fraction of $31 \%$ holds different views. The findings suggest that the Polokwane Local Municipality lacks the agenda of industrial development in its LED plans, thus, it progresses slowly in socio-economic transformation. The finding is supported by the assertion that manufacturing records only a fraction of $0.46 \%$ on the national GDP (City of Polokwane, 2020).

Figure 4: My business creates jobs and alleviate in the community

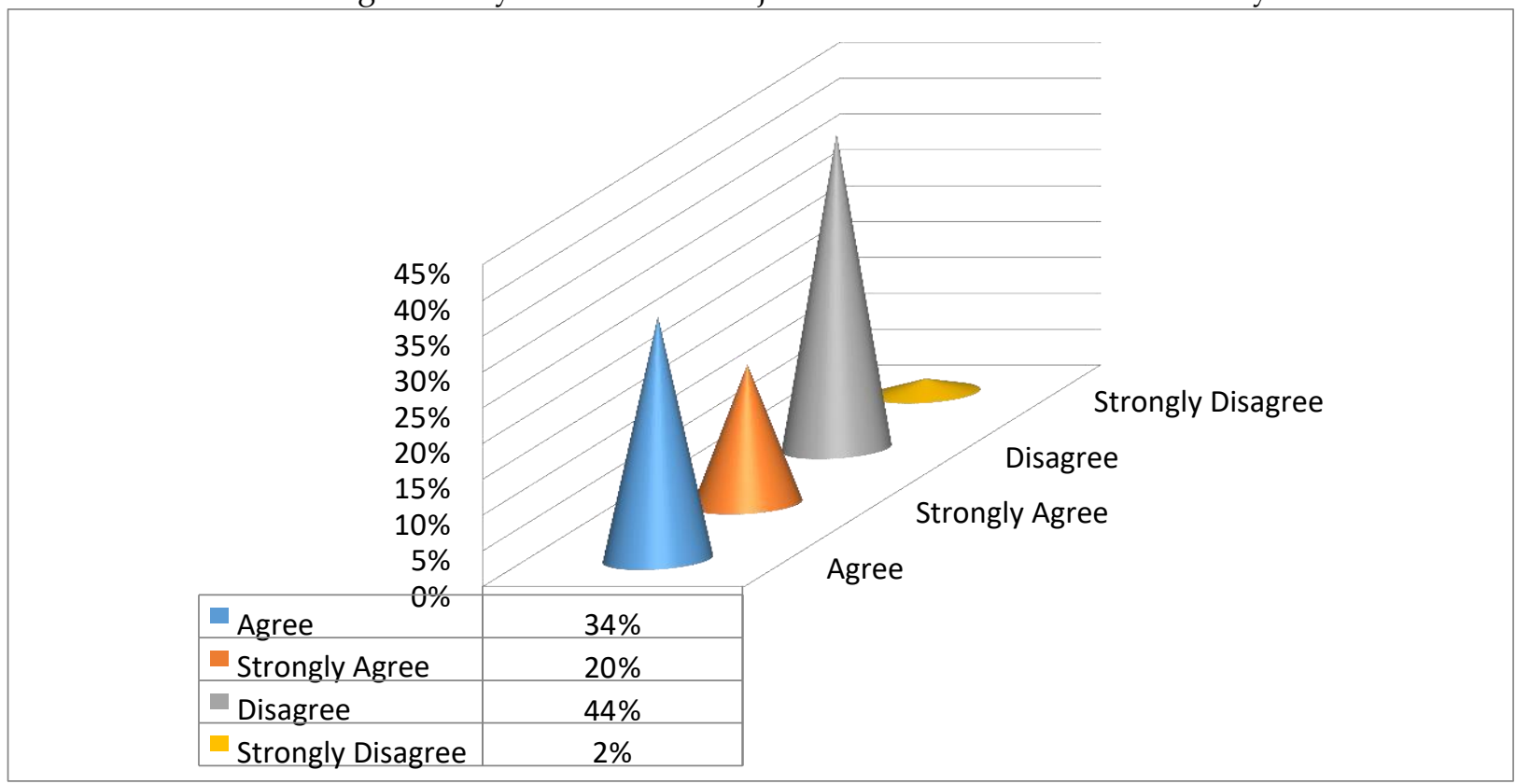

Figure 4 shows that $34 \%$ of the participants agree, followed by $20 \%$ of the participants who strongly agree. $44 \%$ of the participants disagree and $2 \%$ of the participants strongly disagree that their businesses create job opportunities. In total, the findings suggest that the majority of the participants $(54 \%)$ are of the view that their project embodies LED objectives. A fraction of $46 \%$ holds a different perspective. The 
findings suggest that only $54 \%$ of the participants are able to create job opportunities. The findings suggest that the rate of beneficiaries who are able to create job opportunities is not satisfactory given the year that LED was adopted in South Africa. The finding supports the statement that the impact of LED initiatives on job creation is declining (Masuku, Jili \& Selepe, 2016).

\section{Discussion and Conclusion}

The purpose of the paper was to probe the efficacy of LED in South African municipalities with reference to the Polokwane Local Municipality in the Limpopo Province, South Africa. The paper discussed the nature, role and strategies of LED in South African municipalities. The paper gauged the extent in which LED is effective in South African municipalities by evaluating the impact of LED strategies in local economy. The findings reveal that the impact of LED is declining in South African municipalities. The findings also suggest that the strategies of LED in place are not effectively implemented because only a small fraction of the participants agree that indeed the municipality facilitates funding for SMMEs; only a small fraction of the participants are of the view that the LED unit provides adequate infrastructure and creates industries. Moreover, only a fraction of the participants is able to create job opportunities. Based on the empirical findings of the study, the following recommendations are made in order for the LED to have a high impact in local economy:

\section{Facilitate funding for SMMEs}

The White Paper on National Strategy for the Development and Promotion of Small Business mandates municipalities in South Africa to mitigate unemployment through SMMEs (Makhubo, 2015). There are programmes that assist SMMEs with access to finance in South Africa (Meyer, 2014). However, this paper's findings suggest that little is being done to assist SMMEs access financial assistance because $76 \%$ of the participants are of the view that the LED unit does not facilitate funding for SMMEs. SMMEs' access to financial assistance is limited in South Africa, only SMMEs with a credit history have access to financial assistance, particularly in the private sector. The paper, therefore, recommends that the LED unit must facilitate funding for SMMEs in the municipality. The facilitation of funding can include assistance in writing a fundable and feasible business plan in order for local SMMEs to be considered for financial assistance. The LED unit needs to provide local SMMEs with information on how to obtain funding. There has to be LED initiatives that talk to SMMEs funding.

\section{Provide adequate infrastructure}

Infrastructure is linked with the mitigation of unemployment and poverty (International Labour Organisation (ILO), 2021). Infrastructure promotes employment growth (Bond, 2002). Ma, Zhao, Li, and Zhu (2019) examined infrastructure investment of China's government and found that infrastructure investment has a positive effect on economic growth. This paper reveals that $73 \%$ of the participants are of the view that the LED unit does not provide adequate infrastructure. The paper recommends that the LED unit must provide adequate infrastructure and also manage the existing economic infrastructure effectively. Provision of infrastructure stimulates employment growth and attracts investment in the municipality. Rashid, Fazal, Javaid and Kausar (2021) evaluated the nexus of infrastructure investment and economic growth in South Asian countries and found that there is a direct relationship between infrastructure and economic growth. They further state that infrastructure projects enhance economic growth. SMMEs can be attracted and retained by providing adequate infrastructure (Slabbert, 2004). Provision of adequate infrastructure will create short- and long-term job opportunities through construction (ILO, 2021).

\section{Development of industries}

Development of industries can enforce import substitution and promote exports as well as injection of investment. Municipalities can promote export and import substitution by supporting local businesses to produce and export competitive goods (Slabbert, 2004). However, there are only a few manufacturing activities in the Polokwane Local Municipality, recording only $0.46 \%$ in the national GDP in South Africa (City of Polokwane, 2019). Supporting this assertion, the paper reveals that $69 \%$ of the participants are of the view that the LED unit does not create industries in the municipality. To remedy this, the paper recommends that the LED unit should establish manufacturing industries. Industries create job 
opportunities, attract investment and promote import substitution as well as export. Industries will not only create job opportunities but will also attract investment and thus enhancing an inclusive economic development.

\section{Designing LED strategies and initiatives that enhance job creation}

The objectives of LED include mitigating unemployment and poverty in South Africa. However, South Africa records 27.6\% unemployment rate (Stats SA, 2019). Provinces in South Africa have high poverty rates, with the Limpopo Province recording $67.5 \%$ of adults living in poverty followed by Eastern Cape with 67,3\%, KwaZulu Natal with 60,7\% and Northwest with 59,6\% (Statistics South Africa (Stats SA), 2019). This study's findings reveal that $46 \%$ of LED beneficiaries are able to create job opportunities. The findings also suggest that LED is declining in South Africa. The impact of LED on job creation in the Polokwane Local Municipality is low. The strategies in place fail to achieve $100 \%$ job creation rate. The unemployment rate reflects the declining employment growth in South Africa despite the implementation of LED. The study therefore recommends that the LED unit must review LED initiatives and come up with strategies that will promote and enhance job creation. LED needs to look into the opportunities of LED and foster job creation. Each community has its unique resources that pose as opportunities of LED. The paper further recommends that the LED unit should come up with LED policies and strategies in line with opportunities of LED in the municipality.

The proposed recommendation can improve the efficacy of LED in South African municipalities and also evoke further research in improving efficacy of LED in South Africa. The proposed recommendation will promote the manifestation of high LED impact and contribute to the development of effective measures of implementing LED in South Africa. The paper submits that effective measures of implementing LED will enhance LED efficacy and fast track the notion of inclusive economic growth in South African municipalities. Municipalities should put more effort into facilitating funding for SMMEs, provision of adequate economic infrastructure, establishment of industries and overall mitigation of unemployment and poverty.

\section{Limitation and direction for future research}

This paper focused solely on the LED unit in the Polokwane Local Municipality out of 278 municipalities in South Africa. The applicability of paper's findings can be limited to the Polokwane Local Municipality given the diversity of each municipality in South Africa. There was no specific ratio when distributing questionnaires to the beneficiaries of the LED unit. Therefore, some LED beneficiaries could have participated more than the other categories of beneficiaries, which limited the accuracy of the findings. Future research could focus on the impact of infrastructure development on the Local Economic Development in South African Municipalities and challenges that hinder the effectiveness of LED in South African municipalities.

\section{References}

Binza, M.S. (2005). Local Economic Development Beyond Blueprints: A Bottom-Up Approach. Administration Publica, $13(2): 1-33$.

Botes, L. (2002). Institutional capacity of Local Economic Development in the Karoo District Municipality. Local Government Support and Learning Programme. Northern Cape Department of Local Government and DFID (UK), Unpublished Report.

International Labour Organisation. (2021). Infrastructure, Poverty Reduction and Jobs. Geneva: International Labour Organisation.

Kamara, R. D., Leonard, S. and Haines, R. (2017). Enhancing the Capabilities of Municipalities for Local Economic Development through Skills Training. Socio Economic Challenges, 1(4): 35-44.

Koma, S.B. (2014). The Implementation of Local Economic Development Policy: The Case of the Emakhazeni Local Municipality in South Africa. Administration Publica, 22(4): 40-61.

Kroukamp, H. (2006). Corruption in South Africa with Particular Reference to Public Sector Institutions: The Evil of All Evils. Journal of Public Administration, 41 (2.1): 206-217.

Ladzani, M.W. and Netswera, F.G. (2009). Support for Rural Small Businesses in Limpopo Province, South Africa. Development Southern Africa, 26(2): 225-239

Lombard, S., Behrens, R. and Viruly, F. (2017). Value Creation Around Transport Infrastructure in South Africa: The Case of Gautrain. 36 Southern African Transport Conference, 10- 13 July 2017, Pretoria, South Africa. 
Ma, X., Zhao, k., Li, Y. and Zhu, H. (2019). Infrastructure Investment and Sustainable Development in Coastal Areas in China. Coconut Creek: Coastal Education \& Research Foundation, Inc.

Makhubo, T.J. (2015). Local Economic Development as a Tool for Job Creation: A Case of Mafube Local Municipality. Masters Dissertation. School of Basic Science, Northwest University.

Malefane, S.R. (2013). Small Medium, and Micro Enterprise and Local Economic-Base Restructuring: A South African Local Government Perspective. Journal of Public Administration, 48(4): 671-690.

Masuku, M.M., Jili, N.N. and Selepe, B.M. (2016). The implementation of Local Economic Development Initiatives Towards Poverty Alleviation in Big 5 False Bay Local Municipality. African Journal of Hospitality, Tourism and Leisure, 5(4): 1-11.

Mbecke, P. (2015). Municipal Entrepreneurship: An Alternative Strategy to Promote, Improve and Sustain Service Delivery in Local Governments in South Africa. Corporate Ownership \& Control, 12(3): 409-418.

Meyer, D.F. and Venter A. (2013). Challenges and Solutions for Local Economic Development (LED) Municipal Institutional Arrangements: The Case of the Northern Free State. Administration Publica, 21(4): 91-116.

Nel, E.L. and Rogerson, C.M. (2002). LED in the Developing World: The Experience of Southern African. New Brunswick: Transaction Publishers.

Oyedele, L.O. (2012). Avoiding Performance Failure Payment Deductions in PFI/PPP Projects: Model of Critical Success Factors. Journal of Performance of Constructed Facilities, 27(3): 283-294.

Rashid, H.A., Fazal, A., Javaid, Y. and Kausar, N. 2021. Infrastructure and Economic Growth in South Asian Countries. Journal of Indian Studies, 7(1): 81-92.

Reddy, P.S., Sing, D. and Moodley, S. (2003). Local Government Financing and Development in Southern Africa. Cape Town: Oxford University Press.

Republic of South Africa. (1998). White Paper on Local Government. Pretoria: Government Printers.

Republic of South Africa. (2000). Municipal Systems Act, Act No. 32 of 2000. Pretoria: Government Printers.

Slabbert, T.J.C. (2004). An investigation into the State of Affairs and Sustainability of the Emfuleni Economy. Doctoral Thesis. Department of Economics. University of Pretoria.

Statistics South Africa. (2019). Quarterly Labour Force Survey - QLFS Q1:2019. Pretoria: Statistics South Africa.

The City of Polokwane, (2020). 2019/20 Draft Integrated Development Plan. Polokwane: The City of Polokwane. 